\title{
Science in the Study of Ancient Egypt
}

Egyptology has been dominated by the large quantity of written and pictorial material available. This amazing archaeology has opened up a wonderful view of the ancient Egyptian world. The importance of hieroglyphics and texts, and their interpretation, has led to other areas of archaeology playing much less prominence in the study of Egypt. Perhaps most notable in the relatively infrequent application of analytical science to answer Egyptian questions. This problem has been compounded by difficulties in accessing the material itself. In recent years, however, new research by a range of international groups has overturned this historic pattern, and science is now being routinely incorporated into studies of the history and archaeology of Egypt.

Science in the Study of Ancient Egypt demonstrates how to integrate scientific methodologies into Egyptology broadly, and in Egyptian archaeology in particular, in order to maximise the amount of information that might be obtained within a study of ancient Egypt, be it field, museum, or laboratory-based. The authors illustrate the inclusive but varied nature of the scientific archaeology being undertaken, revealing that it all falls under the aegis of Egyptology, and demonstrating its potential for the elucidation of problems within traditional Egyptology.

Sonia Zakrzewski is an Associate Professor in Archaeology at the University of Southampton, where she runs a masters course in bioarchaeology and osteoarchaeology, synthesising both human and faunal studies. She publishes widely in bioarchaeology, physical anthropology and science journals and has edited two books.

Andrew Shortland is Professor of Archaeological Science at Cranfield University. He is Deputy Director of Cranfield Forensic Institute, where he runs a group that specialises in the application of scientific techniques to archaeological and forensic problems.

Joanne Rowland is a Junior Professor in the Ägyptologisches Seminar of the Freie Universität, Berlin. She directs the Minufiyeh Archaeological Survey, and previously was a researcher in the Egyptian Collection at the Royal Museums of Art and History (Brussels) and at the Research Laboratory for Archaeology and History of Art (RLAHA) at Oxford University. 


\section{Routledge Studies in Egyptology}

1. Ancient Egyptian Temple Ritual

Performance, Pattern, and Practice

Katherine Eaton

2. Histories of Egyptology

Interdisciplinary Measures

Edited by William Carruthers 


\section{Science in the Study of Ancient Egypt}

Sonia Zakrzewski, Andrew Shortland and Joanne Rowland 
First published 2016

by Routledge

711 Third Avenue, New York, NY 10017

and by Routledge

2 Park Square, Milton Park, Abingdon, Oxon OX14 4RN

Routledge is an imprint of the Taylor \& Francis Group, an informa business

(C) 2016 Taylor \& Francis

The right of Sonia Zakrzewski, Andrew Shortland and Joanne Rowland to be identified as the authors of this work has been asserted in accordance with sections 77 and 78 of the Copyright, Designs and Patents Act 1988.

All rights reserved. No part of this book may be reprinted or reproduced or utilised in any form or by any electronic, mechanical, or other means, now known or hereafter invented, including photocopying and recording, or in any information storage or retrieval system, without permission in writing from the publishers.

Trademark notice: Product or corporate names may be trademarks or registered trademarks, and are used only for identification and explanation without intent to infringe.

\section{Library of Congress Cataloging-in-Publication Data}

Zakrzewski, Sonia R., author.

Science in the study of ancient Egypt / Sonia Zakrzewski, Andrew

Shortland and Joanne Rowland.

pages $\mathrm{cm}$.-(Routledge studies in Egyptology ; 3)

Includes index.

1. Egyptology-Technological innovations. 2. Egypt-History-

To 332 B.C. 3. Egypt-Antiquities. 4. Archaeology-Methodology.

I. Shortland, Andrew J., author. II. Rowland, J. (Joanne), author.

III. Title. IV. Series: Routledge studies in Egyptology ; 3.

DT60.Z35 2015

932.010721-dc23

ISBN: 978-0-415-88574-4 (hbk)

ISBN: 978-1-315-67869-6 (ebk)

Typeset in Sabon

by HWA Text and Data Management, London 


\section{Contents}

List of Figures $x$

List of Boxes xii

Acknowledgments $\quad x v i$

1 Introduction: Biographies and Lifecycles 1

1.1 What is Egyptian Archaeology? 1

1.2 Archaeology in Egypt: an Egyptian Archaeology 3

1.3 Archaeological Science and the Study of Egypt: Egyptological Science 4

1.4 Studying Objects, or 'Material Culture' 5

1.5 Archaeology in Egypt and How to 'Read' This Book 6

2 The Biography of Time and Space

2.1 Time: Dating Methods (Relative and

Chronometric Dating) 12

2.1.1 Relative Chronology and Relative Dating 14

2.1.2 Absolute Dating 25

2.2 Finding Sites and Buildings (with Kristian Strutt) 50

2.2.1 Remote Sensing and Egyptian Archaeology 50

2.2.2 Geophysical Survey Techniques 62

2.2.3 3-D Site Reconstruction 82

2.2.4 Considerations 82

2.3 The Environment and Palaeoenvironment 82

2.3.1 Environmental Reconstruction 84

2.3.2 Obtaining Environmental Data 85

2.3.3 Animals and Plants 99

2.4 Organisation of Human Burial Grounds 113

2.4.1 Working with Data from Mortuary

Contexts 114

2.4.2 Types of Data and Organisation 117 
3 The Biography of People

3.1 Death and Burial 125

3.1.1 Burial Rites and Rituals 126

3.1.2 Patterning of Burials 132

3.1.3 Burials and Tombs 137

3.1.4 Age and Sex 139

3.1.5 Identification of Children and Childhood 143

3.1.6 Kinship 149

3.2 Activity and Occupation 150

3.3 Health and Disease 158

3.3.1 Trauma 160

3.3.2 Infectious Disease 161

3.3.3 Chronic Conditions and Joint Disease 170

3.3.4 Metabolic Conditions 171

3.3.5 Congenital Conditions 173

3.3.6 Tumours 173

3.4 Diet and Subsistence 174

3.4.1 Dental and Skeletal Markers 176

3.4.2 Isotopic Markers 179

3.4.3 Intestinal Contents, Archaeoparasites and Coprolites 180

3.4.4 Other Evidence 186

3.5 Clothing and Adornment 188

3.5.1 Fabric Remains and Wrappings 189

3.5.2 Ornamentation and Amulets 189

3.5.3 Bodily Adornment and Modification 198

3.5.4 Hair 199

3.5.5 Mummified Animals 200

3.5.6 Other Tomb Items and Equipment 202

3.6 Migration and Mobility 202

3.6.1 Isotopic Methods 203

3.6.2 Other Compositional Signals 209

3.6.3 Skeletal Metric Methods 209

3.6.4 Nonmetric Skeletal and Dental Traits 210

3.7 Social Organisation 217

3.7.1 Age and Social Grouping 217

3.7.2 Social Status and Ranking 218

3.7.3 Population and Ethnicity 219 
4 The Biography and Analysis of Objects

4.1 Identifying the Material Component: What Is It Made From? 225

4.1.1 Inorganic Objects - HH-XRF 226

4.2 Raw Materials 228

4.2.1 The Provenance Hypothesis 228

4.3 Distribution and Consumption 229

4.3.1 Chaine Opératoire? 231

4.3.2 Transport and Supply 238

4.3.3 Production Evidence from Finished Objects 239

4.4 Egyptian Materials 239

4.4.1 Stone 239

4.4.2 Clay and Ceramics 253

4.4.3 Metals 262

4.4.4 Glass 275

4.4.5 Glaze 282

4.4.6 Pigments 287

4.5 Use and Re-use of Objects: The Lifecourses of the Objects 292

4.6 Conservation and Display 293

4.6.1 Field Conservation 294

4.6.2 Identifying Early Conservation 295

4.6.3 Modern Analysis in Collections 296

4.6.4 Storage and Display 304

5 Ankh, Wedja, Seneb at Tell el-Amarna

Appendix I: King List and Summary of Egyptian

Chronology

Appendix II Summary of Some Major Analytical

Techniques and Methods

References

Index 


\section{Figures}

2.1 King list on the wall of the Temple of Seti I at Abydos 26

2.2 Bayesian analysis of dates for two short-lived organic samples, demonstrating the effects of prior information

2.3 Quickbird 432-RGB image, pansharpened with high pass edge detection and a 95\% clip linear stretch, which reveals part of the plan of the southern Roman Period town at Tell Timai

2.4 Magnetic survey map of Tell el-Balamun 68

$\begin{array}{lll}2.5 & \text { Topographic survey being undertaken } & 76\end{array}$

2.6 ERT transverses demonstrating truncation due to increased spacing

2.7 A SmartCart with $500 \mathrm{MHz}$ antenna in operation at Gurob, being pushed by Rais

Omer Farouk el-Quftawi

2.8 Augering alongside Marie Millet's deep sondage SW of the Sacred Lake at Karnak to enable comparison of augered and excavated material and extend records of sediments below the watertable

2.9 Corona satellite image of the Nile river near Merimde Beni Salama, taken on November 9th 1968

2.10 Proportions of the major terrestrial game animals in the prehistoric Nile Valley

3.1 CT imaging to demonstrate craniotomy

3.2 Carbon and nitrogen average isotopic values for infants from the Kellis 2 cemetery

3.3 (A) Phytoliths, dendritic forms, spiny in shape from human gut contents HK43. (B) Epidermal cells from cereals from human gut contents HK43. (C) Phytoliths, rondel forms from human gut contents HK43. (D) Cereal starch grain from human gut contents HK43 (scale bar $20 \mu$ ).

(E) Gelatinized starch from human gut contents HK43 (scale bar $20 \mu$ ) 
3.4 Hand (shown palm up) wrapped in 'resin'-soaked layers of textile. HK43, Burial 16

3.5 (a) 3D virtual reconstruction result, dorsal image; the two pyriform formations are indicated by a square. (b) The leather bag closed by a knot as it appears to the stereomicroscopy observation. (c, d) SEM-EDX results

3.6 Multi-dimensional scaling 2D plot of the 36-trait MMD distances among the 14 Nubian samples

4.1 Map of the Eastern Mediterranean showing the most probable source areas for the fabric groups on the basis of geology

4.2 Composite RTI of the lower part of the so-called Battlefield Palette, lit under normal light or default illumination and using the diffuse gain rendering mode 


\section{Boxes}

2.1 Ceramic Recording in the Field

Janine Bourriau

Senior Fellow, McDonald Institute for Archaeological Research, University of CAMBridge

\section{Peter French}

Visiting Scholar, McDonald Institute for Archaeological Research, University of CAMBridge

2.2 Bayesian Statistics in Egyptology

Felix Höflmayer

Apart-Fellow, Austrian Academy of Sciences,

Institute for Oriental and European Archaeology

2.3 Satellite Archaeology for Egyptology

Sarah Parcak

Associate Professor, Department of Anthropology,

University of Alabama at Birmingham

2.4 Magnetic Survey of the Great Temple Enclosure in Tell el-Balamun

Tomasz Herbich

Deputy Director, Institute of Archaeology and Ethnology, Polish Academy of Sciences

2.5 Topographic Survey

\section{Kristian Strutt}

Geophysical Researcher, Archaeological Prospection Services of Southampton, Department of Archaeology, University of Southampton

\subsection{Migrating Nile: Augering in Egypt}

Angus Graham

Wallenberg Academy Fellow, Department of Archaeology and Ancient History, Uppsala Universitet

\section{Judith Bunbury}

Teaching Fellow, Department of Earth Sciences, University of Cambridge 
2.7 Archaeobotany of the Giza Plateau

Mary Anne Murray

Environmental Archaeologist, University of Copenhagen in Qatar

Claire Malleson

Director of Archaeological Science,

Ancient Egypt Research Associates (AERA)

2.8 Interaction Between Man and Animals in the Prehistoric

Nile Valley

Wim Van Neer

Senior Scientist, Royal Belgian Institute of Natural Sciences, Brussels

Veerle Linseele

Research Associate, FWO-Flanders Katholieke Universiteit Leuven

and Royal Belgian Institute of Natural Sciences, Brussels

2.9 Burial and Mortuary Analysis: Abydos in Practice

Sonia Zakrzewski

Associate Professor, Department of Archaeology, University of Southampton

3.1 An Inside Look at Craniotomy

Andrew Wade

Visiting Researcher, University of Western Ontario

3.2 Breastfeeding and Weaning Practices in Ancient Kellis:

The Stable Isotope Evidence

Tosha L. Dupras

Professor, Department of Anthropology,

University of Central Florida

3.3 Work Patterns at Hierakonpolis, Giza, Abydos and Amarna

Melissa Zabecki

Lecturer, Department of Anthropology, University of Arkansas

3.4 Schistosomiasis - The Immunocytochemistry and ELISA Evidence

Patricia Rutherford

Research Associate, School of Biological Sciences,

University of Manchester

3.5 Ancient DNA Identification of Infectious Diseases in Egyptian Mummies

Albert Zink

Scientific Director, Institute for Mummies and the Iceman,

EURopean ACADEMY

3.6 Gut Contents: A Case Study

Ahmed G. Fahmy

Late of the Department of Botany and Microbiology, Helwan University 
xii List of boxes

3.7 Textile Bindings at Hierakonpolis

Jana Jones

Research Fellow, Department of Ancient History,

Macquarie University, Sydney, Australia

3.8 A Chrysocolla Amulet in a Child Mummy from the Early Dynastic Period

\section{Raffaella Bianucci}

Postdoctoral researcher, Department of Public Health and Pediatrics, UNIVERSITY OF TURIN

\section{Grazia Mattutino}

Technician, Department of Public Health and Pediatrics, UNIVERSITY OF TURIN

3.9 Investigating Ancient Egyptian Migration in Nubia at Tombos using Strontium $\left({ }^{87} \mathrm{Sr} /{ }^{86} \mathrm{Sr}\right)$ and Oxygen $\left(\delta^{18} \mathrm{O}\right)$ Isotope Analysis

Michele R. Buzon

Associate Professor, Department of Anthropology, Purdue University

3.10 Additional Insight into Post-Pleistocene Nubian Population History

Joel D. Irish

Professor, Research Centre in Evolutionary Anthropology and

Paleoecology School of Natural Sciences and Psychology,

Liverpool John Moores University

3.11 The Potential of Genetic Kinship Studies in Ancient Egyptian Human Remains

\section{Abigail Bouwman}

Head of Molecular Group, Institute of Evolutionary Medicine (IEM), UNIVERSITY OF ZURICH

4.1 The Canaanite Amphora Project: Study by Thin Section Petrography

\section{L.M.V. Smith}

Research Fellow, McDonald Institute for Archaeological Research, UNIVERSITY OF CAMBRIDGE

\subsection{Egyptian Quarry Landscapes}

Patrick Degryse

Head of the Division / Professor, Department of Geology, Katholieke Universiteit Leuven

\section{Tom Heldal}

Coordinator, Geological Survey of Norway (NGU) 
4.3 Provenancing Stone and the Red and Black Granites in the Egyptian Antiquity Museum of Turin

Andrew Shortland

Professor/Director, Cranfield Forensic Institute, Cranfield University

4.4 The Vienna System

Janine Bourriau

Senior Fellow, McDonald Institute for Archaeological Research,

UNIVERSITY OF CAMBRIDGE

4.5 Provenancing Oxhide Ingots

Andrew Shortland

Professor/Director, Cranfield Forensic Institute, Cranfield University

4.6 The Ulu Burun Wreck - Exchange in Action

Andrew Shortland

Professor/Director, Cranfield Forensic Institute, Cranfield University

4.7 The Technology of Faience and Glass

Andrew Shortland

Professor/Director, Cranfield Forensic Institute, Cranfield University

4.8 Red-shroud Mummies: Links and Sources

Marc Walton

Research Associate Professor, McCormick School of Engineering and Applied Science, Northwestern University

Andrew Shortland

Professor/Director, Cranfield Forensic Institute, Cranfield University

4.9 Documenting Artefact Surfaces with Reflectance

Transformation Imaging

Kathryn E. Piquette

Research Associate, Cologne Center for eHumanities, Universität zu Köln 